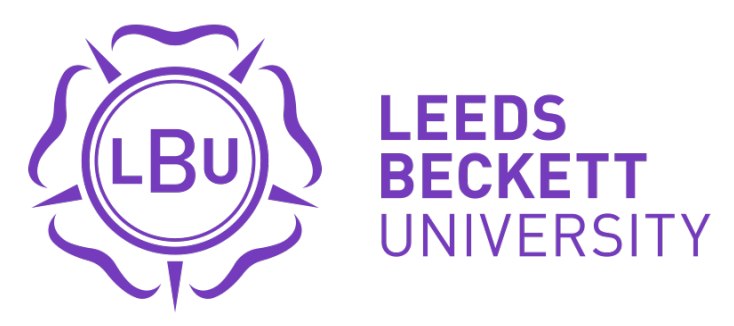

Citation:

Dart, J (2017) Showing Israel the red card. Activists engaged in pro-Palestinian sport-related campaigns. International Journal of Sport Policy and Politics, 9 (3). pp. 521-539. ISSN 1940-6940 DOI: https://doi.org/10.1080/19406940.2017.1292303

Link to Leeds Beckett Repository record:

https://eprints.leedsbeckett.ac.uk/id/eprint/3552/

Document Version:

Article (Accepted Version)

This is an Accepted Manuscript of an article published by Taylor \& Francis in International Journal of Sport Policy and Politics on 17 February 2017, available online: http://www.tandfonline.com/10.1080/19406940.2017.1292303

The aim of the Leeds Beckett Repository is to provide open access to our research, as required by funder policies and permitted by publishers and copyright law.

The Leeds Beckett repository holds a wide range of publications, each of which has been checked for copyright and the relevant embargo period has been applied by the Research Services team.

We operate on a standard take-down policy. If you are the author or publisher of an output and you would like it removed from the repository, please contact us and we will investigate on a case-by-case basis.

Each thesis in the repository has been cleared where necessary by the author for third party copyright. If you would like a thesis to be removed from the repository or believe there is an issue with copyright, please contact us on openaccess@leedsbeckett.ac.uk and we will investigate on a case-by-case basis. 
This is the pre-publication version

To cite this article: Dart, J. (2017) Showing Israel the red card. Activists engaged in pro-

Palestinian sport-related campaigns. International Journal of Sport Policy and Politics. 1-19.

Received 17 Jul 2016, Accepted 03 Feb 2017, Published online: 17 Feb 2017

To link to this article: http://dx.doi.org/10.1080/19406940.2017.1292303 


\title{
Showing Israel the red card. Activists engaged in pro-Palestinian sport-related campaigns.
}

\begin{abstract}
This article explores the motivations of activists involved in pro-Palestinian sports-based campaigns. The activists' intention is to bring pressure to bear upon Israel until it complies with international law and supports the rights of Palestinian people under the universal principles of human rights. In response to expressions of pro-Palestinian solidarity, the Israeli state and its supporters are interpreting such activity as a 'new' manifestation of 'old' antisemitism. In seeking to assess whether such activity is informed by antisemitism, ten semistructured interviews were conducted with activists to examine their motives. Their political biographies were explored as were their views on the use of sport as platform to express support for the Palestinian people and/or their displeasure at Israeli participation in international sport. One central theme in the interviews was the activists' responses to the suggestion that they were motivated by antisemitism. A qualitative content analysis of the interview transcripts revealed a shared observation that the accusation of antisemitism was a 'shameless tactic' used by those seeking to cover up the ongoing injustices experienced by the Palestinian people. Sport was seen as a legitimate platform for political activity, to raise public awareness, and to put pressure on the Israeli state. The findings contribute to a better understanding of activist motivations, the use of sport as a political platform, and the challenges facing sport and its governing bodies.
\end{abstract}

Key words: antisemitism; anti-Zionism; Boycott, Disinvestment and Sanctions; Jews; protest; politics.

\section{Introduction}

In the ongoing struggle between Israelis and Palestinians, sport is becoming a significant battleground for international public opinion. The Israeli state and its sports teams are increasingly subject to attention from activists seeking to highlight the injustices experienced by Palestinian people. The creation of the State of Israel in 1948 in historic Palestine and the subsequent 68 years of occupation (from a settler colonial perspective) have made the Israeli/Palestinian conflict seemingly unresolvable (Chomsky 1999; Morris 2009; Pappé 2007; Said 1992; Sand 2012; Shalaim 2014; Zertal and Eldar 2007). While there has been reconciliation between the Israeli state and its Egyptian and Jordanian neighbours, attempts to secure long-term peaceful relations with the Palestinians, based on a two-state solution, have failed.

The use of sport as an Israeli-Palestinian proxy battlefield is not new and predates the establishment of Israel and the Palestine National Authority (Galily and Ben-Porat 2012; Sorek 2007). Until 1974 Israel participated in the Asian Games (Sports) Federation, after which many nations refused to play against Israeli teams and athletes. Citing the incident in the 1972 Munich Olympics, the Federation subsequently barred Israel from future Asian Games on the 
grounds that Israeli athletes would require additional security. Pressure from various Arab countries led to the expulsion of Israel from the Olympic Council of Asia in 1981, with Israel eventually becoming a full member of the European Olympic Committee in 1994. Whilst relations between the Israeli state and its neighbours have improved, some athletes continue to refuse to complete against Israelis (Richardson 2016).

Similarly, in 1974, the Israel Football Association (IFA) was excluded from the Asian Football confederation after various states refused to play against Israeli teams. Until 1991 the IFA was unaffiliated to any confederation and thus participated in FIFA tournaments and World Cup qualifiers across Asia, Africa, South America and Oceania. In 1991 Israeli clubs started to play in UEFA sanctioned competitions and the IFA officially joined UEFA in 1994. Despite its geographical location Israel has increasingly sought to integrate itself into European competitions, sporting and otherwise. Their presence in European sporting competitions has led pro-Palestinian campaigners to argue that the standards of human rights sought (if not always achieved) in Europe, should apply to all its participants. Rather than holding Israel to a higher standard applied to other countries, pro-Palestinian supporters argue that Israel is failing to meet its basic commitment to the UN's Universal Declaration of Human Rights. In response to expressions of pro-Palestinian solidarity, the Israeli state and its supporters are increasingly interpreting such activity as a 'new' manifestation of 'old' antisemitism. Activists who support the Palestinians and who highlight the behaviour of the Israeli state are accused of being, by accident or design, guilty of antisemitism.

There have been attempts, under the umbrella of 'Sport for Development and Peace' (SDP), to contribute towards peacebuilding in the region. Various organisations and schemes seek to address a particular aspect of the conflict, with high-profile sport-based coexistence programmes ranging from the Peres Center for Peace, the University of Brighton's 'Football4Peace' programme, through various sports-themed activities funded by the UN (UNRWA) including their football clinics operating in refugee camps and the occupied Palestinian territories, to sports activities funded by international and local charities (Fiske 2013; Hay-Sagiv and Ben-Ezer 2011; Schulenkorf and Sugden 2011; Sugden 2010).

This paper explores the motives of activists involved in pro-Palestinian sport-related campaigns. A powerful narrative carried in many sections of the Western European news media, and increasingly found on social media platforms, stems from the Israeli state and its supporters who claim that those who campaign against the actions of the Israeli state are being antisemitic. Although this is not a new assertion, in order to assess the veracity of this accusation, 10 semi-structured interviews were undertaken with activists involved in a range of campaigns and groups, with the proviso they were all linked to sport. Those interviewed were asked if they felt sport was an appropriate site for political protest, why they chose to focus on Israel (and the suggestion they were neglecting other, more significant, human rights issues), and whether they recognized and/or accepted the accusation that their actions were antisemitic. The paper begins by identifying themes that underpin this study: Israel, Zionism and the Palestinians, transnational solidarity movements and the Boycott, Divestment and Sanctions (BDS) movement, and issues of antisemitism. An account is given of the empirical 
data collection before focusing on the motivations and perceptions of those involved in proPalestinian activity.

\section{Israel, Zionism and the Palestinians}

For reasons of space this article cannot address the complex history that surrounds the establishment of the State of Israel and its impact upon the Palestinians. However, it is necessary to briefly sketch the origins of the conflict. Zionist settlers and Jewish refugees began to arrive in Palestine at the end of the 19th century to join a small Jewish community. European Jews, who were subject to repeated pogroms, sought refuge in North America, with others attracted to the ideology of Zionism which sought to create a 'safe haven' for Jews in the Middle East (Morris 2001; Segev 2000 2001; Stanislawski 2016). The arrival of large numbers of Jews in the newly created state in 1948 led to the expulsion, exclusion and oppression of the majority Palestinian population, the process continuing after the 1967 war and the second stage of colonization (Pappé 2007).1

Zionism is a political ideology, premised on land / territory, which sees Jews as both a religious and national group with a right to national self-determination (Stanislawski 2016). It has also been seen as a movement supported by British imperialist ambitions, and one with a negligible foundation in orthodox Jewish faith (Ahmed 2009). With the decline of imperialism and formal empires in the twentieth-century, Israel remains, arguably, one of the last major settlement colonies that rejects indigenous rights (Sand 2012; 2014). At its core Zionism is premised on the belief that a Jewish state is necessary for the survival of the Jewish people. Since its creation in 1948 those critical of its 'Jewish only' ideology have characterised the country as a settler colonial movement, ethnocracy, and/or apartheid state with the appellation 'ethnic democracy' or 'ethnocracy' seen as more accurate than 'liberal democracy'.

Although Israel is constitutionally defined as both a Jewish and democratic state, this definition has been contested by the existence of significant differences in the rights accorded to different national groups within Israel and a significant increase in the influence of religious and revisionist elements within Zionist ideology (Beinart 2013; Shindler 2015; White 2011). The presence of Palestinians continues to inform contemporary Israeli state policy with many scholars electing to view Israel through a settler colonial lens. According to Salamanca et al (2012) a settler colonial structure underpins Israeli state practices and its treatment of the Palestinian (be they inside Israel, in the OPT or in the diaspora), and that in order to understand the continuing subjection of Palestinians by Israelis, the settler colonial structure must be central to any analysis. In order to ensure that Israel remains a Jewish state different legal structures have been developed with Jews having collective rights while minorities (i.e. Christian and Muslim Palestinians) hold individual rights (Turner 2015). Israel has increasingly introduced legislation that discriminates against the native Palestinian population, including control over individual movement, collective punishments, and restricted access to land, water, health and education. Palestinians view the formation of the State of Israel in 1948 as 'al Nakba' (the catastrophe) and have consistently challenged the accepted version of events propagated by the Israeli state and its supporters who often fail to include the looting, 
destruction, expropriation, expulsion and massacre of the Palestinian people, although the (dominant) narrative is being challenged by those offering a counterhegemonic perspective (Pappé 2007; Segev 2000; Shalaim 2014).

\section{Transnational solidarity and the BDS movement}

In response to their overwhelming defeat by the Israel military, Palestinians turned away from the armed struggle and towards civil resistance and disobedience. The two Intifadas ('uprisings') in 1987-1993 and 2000-2005 generated a broadly sympathetic reception from the international community and was followed by the creation of the BDS movement in 2005 (Bakan and Abu-Laban 2009; Barghouti 2011; McMahon 2014). Adopting a human rights approach and drawing inspiration from the successes of the US civil rights movement and South African anti-apartheid campaigns, the BDS movement was endorsed by over 170 individuals and organisations from Palestinian civil society. The BDS movement calls for an end to the occupation and colonisation of all Arab lands, an end to racial discrimination against Palestinian citizens of Israel, and the right of return for the Palestinian refugees as enshrined in UN General Assembly Resolution 194 (adopted December, 1948). The BDS movement argues that Israel should comply with international law and support the fundamental rights of Palestinian people under the universal principles of human rights (Bakan and Abu-Laban 2009). The movement includes groups which concentrate on boycotting Israeli goods, academic institutions and those companies who are seen as complicit in Israel's treatment of the Palestinians (Morrison 2015). It operates a decentralized, grassroots structure with local groups and campaigns largely autonomous, free to develop their own tactics, select their own targets and decide how much they want to work with other Palestinian solidarity groups or the Palestinian BDS National Committee (Morrison 2015).

Popular support for the Palestinians in Western Europe can be traced back to the late 1960s and formed part of a wider struggle against Western imperialism (Ellis 2014). However, as Kelemen (2012) has shown, the political left in Britain have had a complex and fluid relationship with the Israeli state. In the UK today much of the Palestine solidarity activity takes place under the umbrella of the Palestine Solidarity Campaign. Founded in 1982 in response to Israel's actions in Southern Lebanon, PCS is an independent, non-governmental and non-party political organisations opposed to all forms of racism, including anti-Jewish prejudice and Islamophobia (www.palestinecampaign.org). PCS activists have protested at a Sodastream shop in Brighton (Hadfield 2014), an arms factory in Kent (Kent Online 2016), and performances of the Batsheva dance company (Orr 2012). Individuals from across the arts and cultural sectors have refused to appear in Israel stating their appearance might be seen as condoning Israeli government policy (Lim 2012). However, others have chosen to perform in Israel on the grounds that 'bridge-building' between the different communities is better than isolation, a position which echoes that used by those who performed in apartheid South Africa. University campuses have become key sites through an annual 'Israel Apartheid Week' (Barrows-Friedman 2014), and with calls for a boycott of Israeli academic institutions (British Committee for Universities of Palestine 2013; Goldberg 2014; Rose and Rose 2008). In response, the Israeli government has sought to challenge the protests and BDS narrative by 
offering 'scholarships/fellowships' to students willing to actively promote Israel on campuses and on social media (see www.hasbarafellowships.org).

\section{Activists and activism}

Social media and digital activism (Neumayer and Svenssonm 2016) is being increasingly being used by the Israeli government to distribute pro-Israel materials, with its 'Public Diplomacy' programme training activists and leading a coordinated response to BDS activity (Gravé-Lazi 2016). In an attempt to counter the growth of the BDS movement, the Israeli state uses hasbara (Hebrew for explanation) to discredit pro-Palestinian support (Dart 2016), with Israel's version of public diplomacy using skilled debaters and online trolling to make ad hominem accusations of antisemitism aimed at BDS activists. Working with (and funding) organisations and groups not directly associated with Israel, hasbara seeks to generate a counter-deligitimisation narrative against those seeking to delegitimise Israel (Oren 2016). The Israeli state is also turning to legal methods ('from warfare to lawfare' and 'blacklisting') to discredit individuals/organisations who document the human rights abuses of Palestinians and/or propose boycott, disinvestment or sanctions of the Israeli state and/or its settlements (Schulte 2016).2

Athletes have shown support for the Palestinians, including footballer Christian Ronaldo's sporting a Palestinian scarf, Joey Barton tweeting his criticism of the Gaza bombing, and English cricketer Moeen Ali wearing a pro-Palestine wristband (Bacchi 2016; Burdsey 2015; Rice 2014). The most visible expression of sport-related support for Palestinians was instigated by Freddie Kanoute in response to Israel hosting a UEFA tournament in 2013 (Dart 2015). Securing backing from a number of high profile footballers, many signees later withdrew their support; this situation seems to support Roger Walters (Pink Floyd) who claimed many individuals are reluctant to publically criticise Israeli policy for fear of being labelled antisemitic (Gallagher 2016). At lower levels there has seen a visible increase in proPalestinian activity with protests against Israeli sports teams often resulting in sanctioning by sports governing bodies (Al-Mughrabi 2012; MailOnline 2014; Zirin 2014; Gellar 2015). Palestinian support has also been shown by amateur football teams touring Palestine (Fare 2015; Simpson 2016), with demonstrations/protests at football events organized by groups such as 'Football against Apartheid' and 'Red Card Israeli Racism'.

\section{'New' Antisemitism}

The rise of nationalism and the 'far right' across Europe has led to increased incidents of antisemitism, Islamophobia and other race hate crimes (Shroufi 2015). For a more complete understanding of the issues discussed in this paper, antisemitism needs to be considered in combination with anti-Zionism in order to avoid confusion. It essential to acknowledge the distinction between anti-Zionism as a political position and antisemitism as racism specifically directed towards Jewish people. It is increasingly claimed that traditional forms of antisemitism (which attacked individual Jews and communities) has been replaced by attacks on the state of Israel (Goldberg 2015). This claim is partly premised on the assumption that many Europeans 
hold a long-standing (for some pathological) hatred of the Jews (Klug 2013; Tait 2013; Weinthal 2014). Why else, supporters of the Israeli state ask, does Israel attract so much criticism and judgement by standards of behaviour different to those applied to other countries? Sharansky (2004) sees criticism of Israel as a de facto form of antisemitism which undermines Israel's legitimacy and uses double-standards to delegitimise and demonise the Israeli/Jewish state.

In 2014 Prime Minister Netanyahu sought to define Israel as the state for Jewish people, an act which has informed the suggestion that 'Israel' equates with 'the Jew' (Ravid, Lis and Khoury 2014).3 This has become increasingly significant given the rise in antisemitism seen during periods of conflict (Berg 2015). The accusation of 'new' antisemitism has been increasingly levelled against those on the political left, the political right and those associated with political/radical Islam - in short, anyone critical of the actions of the Israeli state (Keleman 2016). Becoming popular in the 1990s, the term 'new' antisemitism first appeared in 1921, a generation before the State of Israel was established (Klug 2013: 469). The Jewish community has long contained an internal conflict between Zionism and anti-Zionism, but with Israel increasingly proclaiming itself as a Jewish state, and some Jews electing to identify with Israel, long-standing antisemitism is seen to be embodied and displaced onto the Jewish state. This hostility towards Israel and Zionism (antisemitism 'by proxy,' see Klug 2003) allows criticism of Israel to be interpreted as both anti-Zionist and antisemetic.

This paper now moves to assess the relationship between Jewishness, antisemitism, Zionism and Israel by interviewing some of those accused of antisemitic behaviour linked to sport. Klug (2013: 478) suggests that in seeking to identify antisemites and acts of antisemitism, one should look at the 'company they keep', their history/pattern of anti-racist activity, the membership of their organisations and their wider political connections. Noting Klug's (2013) statement that the burden of proof is on those who deny the allegation of antisemitism, the paper explores why Israel has gained a special place in human rights activism and why there is no comparable movement against Saudi Arabia, Russia, China or any number of other repressive states.

\section{Method}

A search of the internet identified a number of groups involved in pro-Palestinian support through sport. The organisations were initially contacted via email with a request to interview their members; some organisations and individuals responded, but others did not. The researcher also accessed participants via personal contacts. Participants were included on the basis of being involved in sports-related activism and that their personal experiences would generate insight into the research questions. A semi-structured interview approach was used because it offers the ability to gather data from a number of respondents, on a number of core topics, in a systematic and comprehensive manner (David and Sutton 2010). At the same time it allows sufficient flexibility for the respondents to explain and contextualize their comments. Ten in-depth, semi-structured interviews were undertaken to examine how the activists made sense of their motives for participating in pro-Palestinian activity, their use of sport as a 
platform, and whether they recognized and/or accepted the accusation they were being antisemitic.

In her account of participating in the 2010 Gaza Freedom Flotilla, de Jong (2012) discusses the issue of academic neutrality when researching human rights activism. She explains how her research directly informed her decision to join the Flotilla as an activist precisely because she was dedicated to academic research. Although not currently directly involved in proPalestinian sports-related activity, I share her commitment to "not "merely" strive for peace but rather aim to transform the perception of the current situation from binary conflict into a “classic" human rights struggle' (de Jong 2012: 193).

During the period when I was contacting the different groups, the British news media were reporting the consequences of the British police/state's infiltration of environmental groups during the late 1970s/early 1980s; thus there was a heightened awareness of possible infiltration of activist groups (Lubbers 2015). Israeli security services (both home and abroad) have long infiltrated pro-Palestine groups (Silver 2016) and, given that individual Zionists have been known to infiltrate human rights groups, it soon became apparent that there was suspicion about the researcher and some initial hesitation in agreeing to participate.

It will reassure others in our group that you are ... (member of a political organisation) ... because there was some concern that we don't know if he's a covert Zionist ... they were only half-joking! (Activist 1)

I think it's quite likely we have people on our membership who want to keep tabs on what we're doing. But everything we do is above board, no secrets! You can read all about us. We're not going to be a very good campaign group if we're being secretive! (Activist 5)

The idea that the British state haven't got tabs on activists is nonsense ... the activists I know assume they're being monitored. When I organised a Palestinian solidarity demo last year I went down to the mosque near where I live to give out leaflets and when I got there a friendly policeman said 'hello [name], we heard you were coming down' - I guess they saw it on Facebook - this kind of activity tends to bring the police out (Activist 7).

All participants were given an information sheet and gave their voluntary, informed consent with the study, as approved by my University's ethics committee. Those interviewed were asked if they would be speaking for themselves and/or on behalf of the group of which they were a member. Individuals declined to speak on behalf of their group and participated in the interview as a member of their group. However, some were willing for their group to be identified because they saw a central part of their activism was to publicise the Palestinian issue as widely as possibly. Some also expressed their desire to respond to the accusation that they were motivated (by accident or design) by antisemitism. The characteristics of the interviewees was as follows: 
- Activist 1: Male; very active in Palestine Solidarity Campaign group; marginal interest in sport.

- $\quad$ Activist 2: Male; very active in Red Card Israeli Racism group; strong interest in sport participation.

- $\quad$ Activist 3: Female: very active in anti-fascist, anarchist politics; strong interest in sport participation.

- Activist 4: Male: active in anti-fascist, anarchist politics; strong interest in sport participation.

- Activist 5: Female: very active in Palestine Solidarity Campaign and other proPalestinian solidarity groups; strong interest in sport.

- $\quad$ Activist 6: Male; very active in left wing politics; strong interest in sport participation.

- $\quad$ Activist 7: Male: very active in left/anarchist politics; very strong interest in sport.

- Activist 8: Male: very active in left-wing politics; active in Palestine Solidarity Campaign and other pro-Palestinian solidarity groups; very strong interest in sport.

- Activist 9: Female: very active in Palestine Solidarity Campaign, marginal interest in sport.

- $\quad$ Activist 10: Male: active in radical left politics; very strong interest in sport.

The semi-structured interviews discussed a range of issues: their decision to get involved in this particular issue, the use of sport as a political platform, their response to the suggestion their actions are antisemitic, and whether they had experienced (seen/heard) any antisemitism during their activity. The interviewees also discussed whether there was a double standard in operation - using sport to build bridges with Palestinians whilst using it to sanction Israel. The interviews concluded by exploring their prospects for the campaigns, and by association, the fundamental issues which underpin the Israel/Palestine situation. The interviews were all recorded and lasted between 45 and 90 minutes. The interviews were fully transcribed with the transcripts forming the raw data for content analysis. Qualitative content analysis was used to analyse the transcripts with the first stage involving a close reading to identify patterns and meanings. This was followed by identifying the main categories which were then organised in to subcategories (David and Sutton 2010). Significant, characterising and recurring comments were grouped into categories with the most salient themes and quotations presented below.

\section{Findings and Discussion}

\section{Getting involved and activity}

All those interviewed had been politically active before getting involved in Palestine solidarity. Individuals traced their activism back to the CND movement in the 1960s and 1970s, the antiapartheid movement in the 1970s and 1980s, or the anti-capitalist movement in the late 1990s. Many had been active in trade unions or campaign groups such as Amnesty International. Activist 5 first became involved in football-related campaigning when participating in a Gaza 
march in London and seeing banners from the 'Football against Apartheid' group: 'I googled them and a couple of us from the Liverpool Friends of Palestine (LFOP) contacted them and through them started to work with Red Card Israeli Racism'. Activist 3 had been involved in anti-fascist groups and described their current involvement as being very different from previous activity 'which involved standing around all day leafleting and getting pushed around by the police.' Activist 1 described how they had been involved with the libertarian/anarchist left but 'wanted to do something more practical.' Three activists identified a personal connection with Judaism which informed their decision to become involved. Activist 7 saw their participation in Palestine solidarity activity as,

a logical extension of all the campaigns I've been involved in - at no point was there a conscious decision to say 'right there are a number of campaigns on offer and this is the one I'm going to pick'; it's not a consumer choice model approach to politics. It grew out of the stuff I was involved with and interested in - especially the anti-war movement ... [and] ... sooner or later we were going to have to discuss what was happening in Palestine.

Much of the activity was focused on education and raising awareness through social events, film screenings, or speaking at 'external' events (e.g. trade union or community group meetings) some of which featured Palestinian speakers,

... the Palestinian teachers who came recently were just so pleased-they were almost in tears when they found that there were so many people supporting them-they feel so embattled where they are all seen as, labelled as, terrorists. (Activist 5)

One shared ambition was to get as many people involved as possible. Activity ranged from 'having conversations - one person at a time' to mass leafleting at football grounds with 'banners that have 'Kick Israel out of FIFA' and 'Fight Israeli apartheid' on them' [Activist $8]$.

We must give out some 2000 leaflets each time we go ... with football you're getting to a totally different group of people you wouldn't normally encounter - a potential audience of forty thousand. We leaflet two hours before the game and then finish as there are a lot of us who want to go in and watch the game (Activist 5).

There was a feeling that public opinion was becoming more sympathetic to the Palestinian cause with one activist suggesting that ' $50 \%$ of the population are sympathetic and $50 \%$ are indifferent ... with a tiny minority who come out with pro-Israel arguments.' There was a common sentiment that they were encountering a shift in the public's attitude and identified a disconnect between the general public and the British government, especially since the Gaza bombings in 2014 ,

One of the biggest changes we've seen is the sense that we're winning public opinion. People are becoming increasingly aware, they know so many people are being killed and being made homeless by the bombing - and the disproportionality of it - you don't 
need to be an advanced analyst or expert to realise who's causing the most trouble (Activist 1).

Activists identified those who were most hostile as, unsurprisingly, adopting a strongly proIsrael position with Christian Zionists described by Activist 10 as 'even more rabid and more difficult to talk to than the Zionists'. The Jewish composition of many pro-Palestinian groups was mentioned (unsolicited) by many of those interviewed,

When we went leafleting there were three guys I recognised from my Jewish community who stopped - but I found them to be incredibly ignorant of what was going on in Palestine. I don't want to be speaking to the converted all the time - and every conversation is really useful. I don't hide the fact I come from a Jewish family particularly with other Jews - they are either really shocked or they hate you more and see you as a traitor (Activist 5).

Activist 8 also commented on the participation by Jews in their group,

I would say the backbone, the heartbeat of Palestine solidarity is Jewish. There are some incredibly impressive young Jews and Holocaust survivors - some of whom [have been] through a very difficult journey. I can understand why they were brought up as Zionists ... the horrors of the pogroms and Holocaust - and so a homeland away from the barbarism of European antisemitism did seem the only solution.

There was a commonly expressed recognition that 'not every Jewish person is pro-Israel' and that Jews who were critical of the Israeli state often needed a significant degree of moral courage. Jewish activists were seen as 'better placed' to critique the behaviour of the Israeli state, although as sports writer Mike Marqusee (2010) noted, whenever he criticised the Israeli state he was described as a self-hating Jew.4 For Activist 5 the accusation of being a 'selfhating Jew' was particularly pertinent,

I'm not a religious Jew but what is happening in Israel has encouraged me to put the label (Jew) back on myself - to stick it on even harder - even though I never took it off - to say 'don't talk in my name - this isn't what Judaism is about - you're bringing Jews into disrepute by the way you're (Israeli government and Zionists) behaving'. There are many Jews who are very embarrassed but who don't want to put their head above the parapet because they have relatives in Israel - I've got relatives in Israeland many are too frightened to look at the evidence because they know that if they did, they wouldn't like what they saw.

Being Jewish allowed Activist 5 to express sentiments, that if made by a non-Jew, could be seen as insensitive, and potentially antisemitic,

I come from a Jewish family with family members killed in the Holocaust and it really angers me that the Holocaust is used as an excuse for what Israel is doing. I'm not afraid to say that I think they (the Israeli government) are using the methods the Nazis 
used - and saying that to a Zionist is like a red-rag to a bull - but I think it's absolutely true - and controversial - but when you have got ministers in the Israel cabinet and Knesset talking about putting the Gazans 'on a diet' - where does that come from? When I went to Hebron and saw the Star of David used like a swastika on Palestinian doors I was absolutely shocked.

\section{Using sport}

Those interviewed had varied levels of interest and involvement with sport. Activist 7 recounted how they 'grew up non-political, but a huge sports fan'. He described how he could not marry his interest in sport with his politics, but after

meeting the Palestinian footballer Mahmoud Sarsak changed everything ... his experiences of being arrested by the Israeli state, detained, and going on hunger strike - from that moment it was much easier to draw out the politics of sport and see the terrible apartheid that the Israeli state inflicts upon the Palestinians.

Israel has no compunction at all when it comes to using sport as a weapon-footballs don't get into Palestinian territory, the national football stadium of Palestine in Gaza has been repeatedly bombed - not as a some random act of horror amidst a sea of carnage, but by deliberately targeting Palestinian football and sporting infrastructure because it's a means of taking away Palestinian identity and nationhood (Activist 10).

Activist 1 admitted they were 'an atheist' when it came to anything to do with sport until, during a regular Palestine Solidarity Campaign meeting, they heard about the forthcoming Wales/Israel match (Euro 2016 qualifier). They recognised this would be an opportunity to show that 'the presence of the Israel football team could not be taken for granted and could be used to broaden the debate about whether Israeli national teams should be allowed to play in European sport competitions'. Activist 3 explained how sport offered them an opportunity to

get a bunch of people together - we all play football - and what a great way to get in to Hebron University women's team! I know it's a cliché, but it is an international language - a way of breaking down barriers. We could have gone out and supported the olive harvest and we would have got to know people, but not as quickly as we did.

By contrast, the suggestion that sport could act as a bridge between Palestinians and Israelis was viewed less positively,

I disagree with the bridge building approach. I think it's important to get away from the sense of 'respectability' these things try to create ... and that the more Israel is isolated, like South Africa was, the sooner the better (Activist 9).

'Sport for peace'! I think that serves the interests of the Israeli state by disguising the fact that it isn't about peace - it's a question of a historic injustice and occupation. To talk about 'peace' is meaningless unless you have justice - and the problem is that they 
don't address the fundamental injustice so, for me, it's a form of Israeli PR (Activist $8)$.

Activist 10 recognised there was 'a fine line, and a grey area, and all the other clichés to boot, between sanctioning an athlete or the state and punishing one for the actions of the other'. There was a wide-spread recognition of the need to caution against targeting individual Israelis and focus on institutions and events. Activist 8 drew on their experiences of protesting against Habima (the National Theatre of Israel, see Warschawski 2016) when they came participate in the London 2012 Olympic celebrations,

We made it quite clear this (protest) was not against individual actors - it was because the theatre company accepted support from the Israeli state and because they performed in the settlements. It's the tie-in with the state that is key, it's not about individuals or Jews or even Israelis. We wouldn't call for non-cooperation with an Israeli artist who was funded independently.

There was a common feeling that Israeli clubs and the national football team should be excluded from European football tournaments because they were seen as representing the Israeli state. However, interviewees recognised that there was a

difference between targeting clubs and national organisations such as the IFA and targeting individual footballers; I wouldn't like to see individual athletes, sports men and women targeted for the crimes of the Israeli state - but it all comes back to the distinction between what is anti-Zionism and what is antisemitism - as soon as you start targeting individual players then those lines become blurred (Activist 7).

Activist 8 suggested the Israeli Football Association (IFA) was unable to influence the internal political structures within Israel,

it's not as if the Israeli FA have got the power to demolish the settlements - but they are part and parcel of the Israeli state and for me it's got to be punitive measures against the IFA until such time as Palestinians are able to travel freely to play, they are not being shot in the legs, their teams are allowed to play internationally, until illegal teams from the illegal settlements are taken out of the league.

The Israeli government's annexation of land across the West Bank shows how sport is being exploited for political purposes. The participation of five Israeli football clubs from West Bank settlements in Israeli leagues demonstrates how the Israeli state, and the IFA, are using sport (as part of a wide range of cultural, political and economic activities) in an attempt to normalise the expansion of settlements and normalise the occupation of the West Bank (Judea and Samaria). As Konecny and Lovatt (2016) have noted 'until a peaceful resolution to the IsraeliPalestinian conflict is agreed, FIFA is required to exclude settlement clubs from the Israeli Football Association. Such a step would not constitute a boycott; FIFA would just be respecting its statutes'. 


\section{Comparison with Apartheid South Africa}

In the fight against apartheid South Africa sport played a central role in the struggle for public opinion with some BDS activists adopting the language and tactics used by anti-apartheid campaigners (Di Stefano and Henaway 2014; Lim 2012). There are increasing claims being made that the Israeli state is similar to apartheid South Africa with others calling for Israel to be explicitly identified as an apartheid state (Pappé 2015; White 2011). The fight against South African (SA) apartheid was premised on equal human rights and based on discrimination and racism as opposed to national identity, rights and borders. Thus, there are important differences between the Israel/Palestine conflict given it is based on the right of the Palestinians to a nation state of their own (MacLean 2014). However, it can be argued that both cases are anti-colonial with the abortive Homelands/Bantustan policy making SA also a case of national rights and state borders.5 What both the anti-apartheid and BDS movement share is a desire to achieve universal standards of human rights.

Given the comparisons made in their literature between apartheid South Africa and Israel, the interviewees were asked about this link. The activists recognised the inevitable, and not unproblematic, comparison and the issue of sport and sanctions/boycotts. Some felt there was a valid comparison with apartheid South Africa because the Israeli state was increasingly acting like an apartheid state, not least with the building of a huge (peace/security/apartheid) wall and operating different laws, work permits and travel arrangements for different segments of the population. Activist 5 felt that,

I think you can definitely make that comparison. I feel very strongly that there is an apartheid system. When Desmond Tutu visited Palestine he thought it was actually worse than the apartheid that he had experienced in South Africa. I don't think that someone with such a high profile would say such a thing unless he really believed it.

Activists discussed the increasing opportunity to broach the issue of Palestinian human rights through sport, using the successes of the anti-apartheid movement. However, that did not mean the issues were 'the same.' As the cultural boycott of South Africa intensified, sport became increasingly important to white SA, with the boycott making only a limited impact on its two most important sports (rugby union and cricket) which continued to tour overseas and host private and 'rebel' tours (Booth 1998; 2003; MacLean 2014). While the BDS activists interviewed here may draw succour from the movement in the 1970s, Srikanth (2015), amongst others, cautions against comparing the BDS campaign to the campaign against South African apartheid. An organised boycott campaign against apartheid began in 1959/60, followed by the suspension of the SA Football Association from FIFA in 1963 and from the Olympic 'family' shortly after (Booth 1998; MacLean 2014). 
Activist 8 recognised the potential to overplay the South African parallel but felt that participation in international (sport/cultural) events was as important to white South Africans as it was for the average Israeli citizen. Activist 9 suggested that if we were successful in having Israel excluded from FIFA that would be huge' and that sport,

as with apartheid South Africa - is a very powerful way of getting one's message across. Countries like Israel - like every country - wants to think they are sports people and that they can get kudos and prestige from doing well in sports events - and so I really do think it's a powerful way of getting some form of leverage.

In critical regards, support for the Palestinians was seen to be much less than that given to 'black' South Africans with Activist 8 pointing to where he felt the parallel with South Africa broke down,

the racist regime in South Africa needed a black working class ... because without their labour power they were screwed. It's not as clear in Israel - they don't depend as heavily on Arab labour as the white South African depended on black labour. They (Palestinians) can't wage a meaningful armed resistance in the way ANC did in South Africa - so they are left with a passive resistance and acts of desperate self-destruction - and it's from that the call for BDS originated.

Another key difference highlighted by activists was how during the apartheid era there were a number of nation states, including the USSR, who made boycotting apartheid South Africa a central plank of its sporting policy (Darby 2008; MacLean 2014). While there are examples of individual athletes and occasional state action aimed at sanctioning the Israeli state and its athletes (Amara 2011; Richardson 2016), few inter/national sporting federations offer consistent support to the Palestinians.

\section{'Why are you picking on Israel?'}

The discussion now considers two statements often levelled against pro-Palestinian activists i) questioning the focus on Israel (with the implicit assumption that other causes are more 'worthy' of attention that the Palestinians), and ii) suggesting that those calling for boycott, disinvestment and/or sanctions are engaging in antisemitism. In response to the suggestion that they were unjustly singling out Israel, Activist 5 highlighted the semantics of the question and did not interpret his actions as just being anti-Israel, but instead pro-Palestinian. Asked why they focused on one nation over another, activists typically responded that they did not get involved in one campaign to the exclusion of all others and that,

Yes, I've often been accused of ignoring other countries with worse poor human rights records. Zionists regularly come out with [that] and I find it very irritating. If you ask other people who are supporting the Palestinians about their politics, they are interested in other issues, but you can only do so much-you may inform yourself about other issues, you may even get involved, but you can't be actively involved in every single issue. Anyway, I now tend to turn it back on them and ask them what issues they're involved with ... how many?! (Activist 5). 
Activist 8 stated that even though he was campaigning against the Israeli state,

it's not as if you turn your eyes way from injustice elsewhere. But there is a particular character to the ongoing persecution of Palestinians and the ongoing occupation of their land. Israel has received all sorts of preferential treatment ... and the longevity of the issues and injustice and racism - it's been going on for decade after decade after decade and resolution after resolution from the $U N$ - are all just blithely ignored (Activist 8).

Activists differed in terms of their knowledge of the region, and whilst few claimed to be 'experts' in the politics of the Middle East, they all felt sufficiently well-informed on the region's history. All those interviewed were British citizens and some felt a particular responsibility because 'their country' had been central to the Middle East's recent history.6 In an attempt to find out their views on other sports-related campaigns, the activists were asked why they felt there had been only limited protests against China (2008) and Russia (2014) hosting Olympic Games, and Qatar's bid to host FIFA World Cup in 2022. Many disagreed with the premise of the question and explained that they had been involved in other sportrelated campaigns but that,

the treatment of the Palestinians by the Israeli state has become more vicious and far nastier than ever before. The horrors of 'Operation Protective Edge' were such that people I knew who weren't political were horrified by the news reports they saw each night on TV - whether it was the boys killed on the beach while playing football or the macabre scenes of people being wheeled in and out of hospital - the horrors were such that people had no option but to get involved (Activist 7).

As the above extracts illustrate, whilst many states have poor human rights records, choosing to participate in support of the Palestinians does not automatically put Israel at the top of a league table of human rights abusers. Ryall (2006) has noted that no country has a 'perfect' human rights record and were 'perfect' criteria to be identified and applied, no country could ever host an international sports event. As Dein and Calder (2007) have pointed out, how one might draw a line between approved and failing states (in a non-hypocritical fashion) is a highly complex, philosophical matter. For the activists interviewed here, philosophising about which of the world's problems to address was not being used as an excuse for inaction. As Marqusee (2014) has pointed out, the logic of choosing not to get involved in a particular issue would leave every struggle isolated from international support.

\section{Are you being antisemitic?}

A central strand in the current debate is that critics of Israel often fail to distinguish between Jews and Israelis. The second statement made to the pro-Palestinian activists was that their actions, deliberate or unintended, were antisemitic. There was a common feeling amongst those interviewed that this denunciation was deployed in order to allow the Israeli state to be free from criticism and to undercut support for the Palestinian people. Activist 3 stated that she was 
'not willing to entertain the accusation that by being pro-Palestine I am being antisemitic' and that 'antisemitism doesn't line up with my antifascist politics'. This sentiment echoed throughout all the interviews and forms the main crux of the argument being considered in this article.

Accusing a long-standing antiracist of being antisemitic generated an irritated response from Activist 8,

I get very angry when I get called antisemitic - I know that's their intention - but nevertheless I still do - it's a coward's way out to throw that accusation. I try not to lose my temper, but the last time I did was when I encountered some Judea and Samaria protestors and they started to call me a racist and antisemite. I've spent all my adult life in various antiracist and left-wing movements. I've a huge affection for Jewish culture and, for me, one of the great tragedies of Zionism is how it weakened that element which was central to a lot of progressive thinking in Eastern Europe.

There were common statements that no form of racism or discrimination was tolerated in their groups and activities,

In fact some people were asked to leave our group because it was felt that some of their campaigning was drifting into antisemitism. It weakens the case of what we are seeking for the Palestinians. When we go leafleting some of those who come up to the stall say 'Yes I agree with you - the Jews!' - but we don't need friends like that - and when we tell them that this is not what we are about - and ask for our leaflet back - they are not very happy! (Activist 5)

There was a recognition that antisemitism did exist but there was a vehement rejection that they were antisemitic.

It's the oldest, most deeply rooted form of racism - it's so deep in our culture - it goes back to Chaucer and earlier - and it's vital we oppose any appearance of it - but the worst way of doing that is by calling things antisemitic that aren't antisemitic and creating confusion between legitimate criticism of a government's brutal inhumane policy and a racist ideology - they are not the same thing! (Activist 8)

When discussing anti-Zionism and antisemitism it is important to recognise that, contrary to Israeli claims, anti-Zionism does not necessarily entail antisemitism. The activists agreed that all forms of racism should be monitored and differentiated so as to identify specific forms of discrimination. However, there was concern over some of the 'so-called, self-appointed, antisemitism monitoring groups' some of which were seen as being too closely aligned to the Israeli state (Lerman 2015). There was recognition that antisemitism had increased, partly as a result of the policies of the Israeli government, and the conflation of Israel and Zionism with Jewishness,

When people see Israel behaving the way it does, because Israel proclaims itself as a Jewish state, people naturally make that connection. The Israel state has a vested 
interested in promoting antisemitism because they can then claim Israel is a safe haven. They have done that for decades ... ever since its establishment when they encouraged other states to expel their Jewish population. After the Paris attacks they (the Israeli government) were very happy to say that they (Jews) weren't safe in their own countries and so they should move to Israel - but I can't think of many countries that are less safe! (Activist 5).

The growing geo-political significance of religious faith has intensified the conflation and confusion between Israel/Zionism and Jewishness. The rise of faith as a social identity marker, especially by the Israeli state, can help to explain the rise in antisemitic attacks in Western Europe. Until the Second Intifada (2000-2005) the Israel/Palestine conflict was primarily seen as a national issue (liberation or otherwise). More recently it has been presented as a clash between Jews and Muslims, rather than between Zionist/Arab or as a struggle between coloniser and colonised. 7 The conflation of Israel, Zionism, Jewishness and antisemitism lies at the heart of conflict with a failure (or unwillingness by some) to point out the essential differences, which perpetuates confusion,

I continually have this conversation 'I'm not talking about Jews, I'm talking about Israel.' It all comes back to the very basic blurring which Zionists attempt to force on the conversation that they are the same thing - that Jewishness and being Israeli are the same thing - or that Jewishness and Zionism are the same thing - but they are not - and you just have to keep banging on trying to make that point (Activist 8).

The idea that people are pursuing some kind of antisemitic agenda through criticising Israel just doesn't stand up. The very idea that criticising Israel for killing hundreds of Palestinian children during Operation Protective Edge somehow marks you out as an antisemite is ludicrous. The horrors of what Israel has perpetuated are so undeniable that they are now in a position where their only response is to label people as antisemites (Activist 7).

In discussion on whether they had seen or heard any antisemitism in the course of their activities, there was a common recognition that political activity would necessarily involve engaging with a wide range of individuals who possess varying levels of political consciousness. It was viewed as inevitable that in building a broad front/united coalition of Palestinian supporters it was likely that, at times, individuals who held antisemitic views would be encountered. However, these individuals were on the fringes, few in number and always challenged,

In my experience the line is so thick and bold and obvious that being anti-racist, antifascist and pro-Palestine is by no means antisemitic - they really are very different. There may be some circles where there is antisemitism with a pro-Palestinian slant but never in our group (Activist 3). 
I can think of only one occasion when I've thought that somebody had worded something incorrectly; I didn't doubt the point they were trying to make - what they were talking about, in no way, had any antisemitism lurking below the surface - but it brought a stinging rebuke - they accepted the point and we moved on (Activist 10).

Other than the very occasional careless use of the word Jew instead of Zionist - which can happen in conversation - when people talk about Israel and use the word Jewbut that always gets picked up and corrected. There are antisemites around but they tend to be in groups like 'Britain First' and the right wing groups - not in pro-Palestine groups (Activist 9).

There was agreement that in responding to expressions of antisemitism it was important not to ignore or dismiss individuals but, through the strength of the argument, to convince them that their approach was misguided. The language used was thus very important in persuading others and building the campaigns. Klug (2013) accepts that antisemitism can be expressed though anti-Zionism and proposed that the burden of proof is on those who deny the allegation of antisemitism. Klug (2013) also suggests that, in seeking to assess whether an individual is being antisemetic, one should look to the company they keep. All those interviewed challenged any and all forms of race hate and, whilst not denying that there had been isolated incidents of antisemitism, pointed out these incidents, language and individuals were all directly and immediately addressed. As one activist suggested, individual racists and antisemites were more likely, and perversely, to be found alongside Zionist groups campaigning against 'radical Islam'.

\section{Pessimism of the intellect, optimism of the will?}

The interviews concluded with the activists reflecting on future prospects and their preferred 'solution'. There was a sense of realism, tempered with optimism, with many suggesting that the short-term prospects did not look positive. Some felt more optimistic and pointed to how Israeli/Zionist opinion was finding it increasingly difficult to maintain a dominant narrative and pointed to an increasing polarisation between 'young settlers [who are] are vicious and racist and fascistic ... [and] ... a growing body of young Jewish Israeli opinion [who are] finding it harder and harder to swallow all the lies' (Activist 10). There was broad agreement on the futility of proposing a two-state solution; so many 'facts on the ground' were being created that the only just solution would be the creation of a single, democratic secular state.

Activists expressed their desire to build upon the growing sense of public sympathy and to create practical actions with positive consequences for the Palestinian people. They spoke of their frustration with mainstream politicians who offer 'support' for the Palestinians but fail to uphold existing international laws. There were mixed feelings on the creation of sports-based campaigns; securing high profile athlete support was seen as unlikely given the difficulty in contacting players because they were 'shielded' by their agents and an unwillingness to do anything that might damage the athlete's 'brand'. A more immediate objective was to establish 
a higher profile for the BDS movement with activists drawing succour from the anti-apartheid campaigns in the 1970,

which had a long fuse and then quick changed: we have got to keep up that optimism. You start from a position you personally think is important - what you think is rightand you might not get to see in your lifetime - but at least you know, you can go to the grave knowing that you played a part - to keep going and just do what you can - we've all got something we can contribute (Activist 6).

For Salamanca et al (2012), the goal for committed scholarship and liberatory movements should be to develop praxis that re-establishes decolonisation and liberation. They suggest that, when looking for an appropriate comparison for Israel, one should look to South Africa, Rhodesia and French-Algeria, along with earlier settler colonial formations (the USA, Canada and Australia), as being more apposite than the contemporary European democracies which Israel seeks to identify with. An internationalist approach which sees the Palestinian struggle as being against Zionist settler colonialism is more likely to be successful when empowered by, and embedded within, a broader struggle against all forms of imperialism and racism (Salamanca et al 2012:5).

\section{Conclusion}

This study has offered an insight into the motivations of activists involved in different sportsthemed pro-Palestinian campaigns and explored the accusation that their activities constitute a new manifestation of old antisemitism. Ten semi-structured interviews showed that they had all been active in a range of political issues before becoming involved in pro-Palestine support. The key theme in this research was the activists' responses to the accusation that they were motivated by antisemitism. Responding to Klug's (2013) proposal to 'look at the company they keep', those interviewed had a long-standing involvement in left-wing, anti-racist, human rights and social justice groups with their motivation entirely free from any form of antisemitism. There was no individual or group concession to antisemitism, with their motivation stemming from an abhorrence of the consequences created by the political ideology of Zionism. The accusation that they were motivated by antisemitism was seen as a tactic used by the Israeli state and supporters of Zionist ideology to discredit them as individuals, discredit their activity and undermine support for the Palestinians.

As Corrigan (2009) has noted, viewing criticism of Israel and Zionism as somehow being antisemetic has no rational basis, just as it makes no sense to see criticism of South African apartheid as being evidence of racism towards whites, or criticism of Nazi policies towards Jews as somehow being evidence of racism towards all German peoples. Many of the activists felt that the expansionist Israeli and Zionist political agenda would go unchecked until it was subject to direct and sustained pressure; given this was unlikely to come from within the country, the international community were therefore central to highlighting the Palestinian cause and pressing for boycott, disinvestment and sanctions. de Jong (2012) recognises the 
depiction of the contemporary situation in Israel/Palestine as a human rights struggle and not as a 'value free' exercise; in much the same way academics, sport governing bodies, and sportsmen/women were involved in the struggle against South African apartheid, these same parties will be required to examine their own position in relation to the Israel/Palestine conflict.

The activists were as one in recognising that in order to maintain credibility for their campaign, a clear and absolute distinction was needed between anti-Zionism and antisemitism, and to distinguish between individual Jews and the action of the State of Israel. As Klug (2013: 470) has suggested 'if Zionism is seen as the only alternative to antisemitism, then it follows that hostility to Zionism (or to the state of Israel as the expression or fulfilment of Zionism) must be anti-Semitic'. Opposing Zionism, as a political ideology, should not automatically be seen as being racist or antisemitic. However, the Israeli state has deliberately sought to exploit antisemitism by conflating Zionism with Judaism and has sought to create a situation in which any criticism of Israel or Zionism is seen as antisemitic. This tactic has proved effective in closing down criticism of the State of Israel (Greenwald and Fishman 2016; Habeeb 2016; Rude 2016).

The attempts to contribute towards peacebuilding in the region through sport-based coexistence projects focus on different aspects of the problem, with more research needed on the extent to which they (are able to) address the root causes of the conflict, bearing in mind Dart's (2015, 2016) suggestion that when it comes to national security, sport features in a very minor capacity. However, the activists interviewed here shared the goal of using sport to raise awareness and bring about pressure on the Israeli state to address its behaviour towards the Palestinians. At present, there is little sign of a coordinated sport-based campaign, due in part, to the range of sports involved and the loose structure of the BDS movement. While MacLean's (2014) discussion of sporting boycotts suggests serious limitations in a sport-focused campaign that adopts the South African model, activities likely to gain traction will be those which focus on Israel's participation in European soccer competitions; these matches have, and will continue, to present activists with multiple opportunities to bring attention to the Palestinian cause. Ultimately, there needs to be political will on both sides; the lack of sincerity expressed by successive Israeli governments, coupled with the fractured Palestinian leadership has resulted in the failure to deliver any meaningful progress.

Acknowledgement: The author would like to thank those who commented on drafts of this article and the reviewers for their careful reading and observations.

\section{References}

Amara, M., 2011 'Olympic sports and internationalism debates in the Arab-Muslim world'. In Preuss, H. and Liese, K., (Eds) Internationalism In The Olympic Movement. Germany, Springer/VS. Pp37-52 
Bacchi, U., 2016, Cristiano Ronaldo and the Palestinians. International Business Times. Available at http://www.ibtimes.co.uk/cristiano-ronaldo-palestinians-1543518

Bakan, A. and Abu-Laban, Y., 2009. Palestinian resistance and international solidarity: The BDS campaign. Race \& Class 51: 29-54.

Barghouti, O., 2011. BDS: The Global Struggle for Palestinian Rights. Chicago, IL: Haymarket Books.

Barr, J., 2012, A Line in the Sand: Britain, France and the struggle that shaped the Middle East. London, Simon and Schuster.

Barrows-Friedman, N., 2014. In Our Power: U. S. Students Organize for Justice in Palestine. Just World Books.

Beinart, P., 2013. The Crisis of Zionism. New York, Picador.

Ben-Porat, A., 2008. Death to the Arabs: the right-wing fan's fear. Soccer \& Society. 9(1): 113.

Berg, S., 2015. UK anti-Semitism hit record level in 2014, report says. BBC News. Available at: http://www.bbc.co.uk/news/uk-31140919

Booth, D., 1998. The Race Game: Sport and Politics in South Africa. Abingdon, Frank Cass.

Booth, D., 2003. Hitting Apartheid for Six? The Politics of the South African Sports Boycott. Journal of Contemporary History. 38(3): 477-493.

British Committee for Universities of Palestine, 2013. Newsletter 63. April. Available at http://www.bricup.org.uk/documents/archive/BRICUPNewsletter63.pdf

Burdsey, D., 2015. Un/making the British Asian Male Athlete: Race, Legibility and the State. Sociological Research Online, 20 3) 17 Available at http://www.socresonline.org.uk/20/3/17.html

Burston, B., 2016. BDS, Springsteen, and Heresies of the anti-Israel U.S. Left. Haaretz. Available at http//www.haaretz.com/opinion/.premium-1.717685

Chomsky N., 1999, Fateful Triangle: The United States, Israel and the Palestinians. London, Pluto Press.

Corrigan, E., 2009 Is anti-Semitism anti-Semitic? Jewish Critics Speak. Middle East Policy XVI(4): 146-159. 
Darby, P., 2008. Stanley Rous's 'own goal': football politics, South Africa and the Contest for the FIFA presidency in 1974. Soccer \& Society, 9(2): 259-272.

Dart, J., 2015. Israel and a sports boycott: Antisemitic? Anti-Zionist? International Review for the Sociology of Sport. Published online before print April 24, 2015, doi:

$10.1177 / 1012690215583482$

Dart, J., 2016. 'Brand Israel': hasbara and Israeli sport. Sport in Society: Cultures,

Commerce, Media, Politics. Published online before print 13 Jan 2016

doi:10.1080/17430437.2015.1133595

David, M. and Sutton, C., 2010. Social Research: the basics, London: Sage (2nd edition)

Dein, E. and Calder, G., 2007. Not cricket? Ethics, rhetoric and sporting boycotts. Journal of Applied Philosophy, 24(1): 95-109.

Di Stefano, P. and Henaway, M., 2014, Boycotting Apartheid from South Africa to Palestine. Peace Review. 26(1): 19-27

Ellis, S., 2014. Promoting solidarity at home and abroad: the goals and tactics of the Vietnam Anti-Vietnam War movement in Britain. European Review of History, 21(4): 557-576.

Fare, 2015. UK women's teams visit Palestine in solidarity football tour. FARE network. Available at http://www.farenet.org/news/uk-womens-teams-visit-palestine-solidarityfootball-tour/

Fiske, G., 2013. PA objections doom Barcelona soccer match against Israel-Palestinian team. Times of Israel. Available at http://www.timesofisrael.com/barcelona-wont-hold-matchagainst-joint-israeli-palestinian-squad/

Galily, Y. and Ben-Porat, A., 2012. (Eds.) Sport, Culture and Ideology in the State of Israel. London: Routledge

Gallagher, P., 2016. Roger Waters: Pink Floyd star on why his fellow musicians are terrified to speak out against Israel. The Independent. Available at http://www.independent.co.uk/news/people/roger-waters-pink-floyd-israel-boycott-banpalestine-a6884971.html

Gellar, R., 2015. Palestine, the IRA, and a soccer team's solidarity. Vice Sports. Available at https://sports.vice.com/en_us/article/palestine-the-ira-and-a-soccer-teams-solidarity

Goldberg, D., 2014. Australian court drops racism case against professor who backs BDS. Haaretz. Available at http://www.haaretz.com/jewish-world/.premium-1.605672 
Goldberg, J., 2015. Is It Time for the Jews to Leave Europe? The Atlantic. Available at http://www.theatlantic.com/magazine/archive/2015/04/is-it-time-for-the-jews-to-leaveeurope/386279/

Gravé-Lazi, L., 2016. Training activists in the social media war against BDS. The Jerusalem Post. Available at http://www.jpost.com/Israel-News/Training-activists-in-the-social-mediawar-against-BDS-459329

Greenstein, R., 2011. Israel / Palestine and the Apartheid analogy: Critics, apologists and strategic lessons. In Lim, A. (Ed.) The Case for Sanctions Against Israel. London, Verso.

Greenwald, G. and Fishman, A., 2016. Greatest Threat to Free Speech in the West: Criminalizing Activism against Israeli Occupation. The Intercept. Available at https://theintercept.com/2016/02/16/greatest-threat-to-free-speech-in-the-west-criminalizingactivism-against-israeli-occupation/

Habeeb, S., 2016. Cry anti-Semitism: Israeli conference targets BDS. Middle East Eye. Available at http://www.middleeasteye.net/columns/cry-antisemitism-israeli-conferencetakes-aim-bds-1765488731

Hadfield, G., 2014. EcoStream store closes after anti-settlement protests. Brighton and Hove Independent. Available at http://brightonandhoveindependent.co.uk/ecostream-store-closesanti-israel-protests/

Hay-Sagiv, T., Ben-Ezer, I., 2011. It is more than a game. Palestine-Israel Journal of Politics, Economics \& Culture. 17(3/4):97-102.

IMEMC, 2016. London High Court Rules in Favor of BDS Groups. International Middle East Media Centre. Available at http://imemc.org/article/london-high-court-rules-in-favor-ofbds-groups/

Jacobs, S., and Soske, J. (Eds.) (2015). Apartheid Israel: The Politics of an Analogy. Chicago, Haymarket.

Kelemen, P., 2012. British Left and Zionism: History of a Divorce. Manchester, Manchester University Press.

Kelemen, P. 2016. Antisemitism and the left. RedPepper. Available at http://www.redpepper.org.uk/antisemitism-and-the-left/

Kent Online, 2016. Broadstairs factory targeted by anti-arms protesters. Available at http://www.kentonline.co.uk/thanet/news/protesters-target-kent-drone-factory-39653/ 
Klug, B., 2003. The collective Jew: Israel and the new antisemitism. Patterns of Prejudice. 37(2): 117-138.

Klug, B., 2013. Interrogating 'New Anti-Semitism. Ethnic and Racial Studies. 36(3): 468482.

Konecny, M. and Lovatt, H., 2016. Why does FIFA still recognise Israeli settlement teams? www.aljazeera.com. Available at http://www.aljazeera.com/indepth/opinion/2016/06/fifarecognise-israeli-settlement-teams-160629093205191.html

Lerman, A., 2015. The 'new antisemitism'. Centre for Research on Migration, Refugees and Belonging. Discussion Paper Series: September 2015. University of East London

Lim, A., (ed.), 2012. The Case for Sanctions against Israel. London: Verso.

Lubbers, E., 2015. Undercover Research — Corporate and Police Spying on Activists. An Introduction to Activist Intelligence as a New Field of Study. Surveillance \& Society. 13(3/4): 338-353.

MacLean, M., 2014. Revisiting (and Revising?) Sports Boycotts: From Rugby against South Africa to Soccer in Israel. The International Journal of the History of Sport. 31(15): 18321851.

MailOnline, 2014. Israeli football players are attacked with flying kicks by pro-Palestinians who invade the pitch during friendly match in Austria. MailOnline. Available at http://www.dailymail.co.uk/news/article-2703713/Maccabi-Haifa-s-friendly-Lille-stoppedearly-pro-Palestinian-protesters-storm-pitch-ATTACK-players.html

Marqusee, M., 2010. If I Am Not for Myself: Journey of an Anti-Zionist Jew. London, Verso.

Marqusee, M., 2014. Further on BDS and 'singling out' Israel. Links: International Journal of Socialist Renewal. Available at: http://links.org.au/node/3672

McMahon, S., 2014. The Boycott, Divestment, Sanctions campaign: contradictions and challenges. Race \& Class, 55(4): 65-81

Media Mole, 2014. Louise Mensch accidentally calls the father of modern Zionism an antiSemite. New Statesman. Available at: http://www.newstatesman.com/media-mole/2014/08/ louise-mensch-accidentally-calls-father-modern-zionism-anti-semite

Morris, B., 2001. Righteous Victims: A History of the Zionist-Arab Conflict, 1881-2001. New York, Vintage Books.

Morris, B., 2009. 1948: A History of the First Arab-Israeli War. Yale University Press. 
Morrison, S., 2015. Organising the Boycott, Divestment and Sanctions movement: the case of the 'We Divest' campaign, Conflict, Security \& Development, 15(5): 575-593

Neumayer, C. and Svensson, J., 2014. Activism and radical politics in the digital age: Towards a typology. Convergence: The International Journal of Research into New Media Technologies. 22(2): 131-146.

Oren, A., 2016. Israel setting up 'dirty tricks' unit to find, spread dirt on BDS groups. Haaretz. Available at http://www.haaretz.com/israel-news/.premium-1.725684

Orr, M., 2012. Don't dance with Israeli apartheid. Socialist Review. Available at http://socialistreview.org.uk/373/dont-dance-israeli-apartheid

Pappé, I., 2007. The Ethnic Cleansing of Palestine. Oxford: Oneworld Publications.

Pappé, I., 2015. Israel and South Africa: The Many Faces of Apartheid. London, Zed Books.

Ravid, B., Lis, J. and Khoury, J., 2014. Netanyahu Pushing Basic Law Defining Israel as Jewish State. Haaretz. Available at http://www.haaretz.com/israel-news/1.588478

Rice, S., 2014. Joey Barton and Yossi Benayoun become involved in Twitter row over IsraelGaza conflict. The Independent. Available at http://www.independent.co.uk/sport/football/news-and-comment/joey-barton-and-yossibenayoun-become-involved-in-twitter-row-over-israel-gaza-conflict-9628185.html

Richardson, V., 2016. Israeli athletes in Rio endure 'shocking' hostility, taunting by Muslim nations. The Washington Times. Available at http://www.washingtontimes.com/news/2016/aug/10/israeli-athletes-rio-olympics-endureshocking-host/

Rogan, E., 2016. The Fall of the Ottomans: The Great War in the Middle East, 1914-1920. London, Penguin.

Rose, H. \& Rose, S., 2008. Israel, Europe and the academic boycott. Race \& Class, 50: 1-20

Rude, E., 2016. Challenging free speech on behalf of Israel. Socialist Worker. Available at https://socialistworker.org/2016/03/21/challenging-free-speech-on-israels-behalf

Ryall, E., 2006. Cricket, politics, and moral responsibility: Where do the boundaries lie? In: L. Howe, H. Sheridan and K. Thompson (eds) Sport, Culture and Society: Philosophical Reflections. Boston, MA: Meyer \& Meyer. 8-45.

Said, E., 1992. The Question of Palestine. New York, Vintage. 
Salamanca, O., Qato, M., Rabie, K. \& Samour, S., 2012. Past is Present: Settler Colonialism in Palestine. Settler Colonial Studies. 2(1):1-8

Sand. S., 2012. The Invention of the Land of Israel: From Holy Land to Homeland. London, Verso.

Sand, S., 2014. How I Stopped Being a Jew. London, Verso.

Shindler, C., 2015. The Rise of the Israeli Right. Cambridge, Cambridge University Press.

Schneer, J., 2011. The Balfour Declaration: The Origins of the Arab-Israeli Conflict. London, Bloomsbury.

Schulenkorf, N. and Sugden, J., 2011. Sport for Development and Peace in Divided Societies: Cooperating for Inter-Community Empowerment in Israel. European Journal for Sport and Society. 8(4): 235-256

Schulte, E., 2016. How do you stop a blacklist? Socialist Worker. Available at https://socialistworker.org/2016/08/04/how-do-you-stop-a-blacklist

Segev, T., 2000. The Seventh Million: The Israelis and the Holocaust (trans. H. Watzman). New York, Owl Books.

Segev, T., 2001. One Palestine, Complete: Jews and Arabs under the British Mandate. London, Abacus.

Shalaim, A., 2014. The Iron Wall: Israel and the Arab World. London: Penguin.

Sharansky, N., 2004. 3D Test of Anti-Semitism: Demonization, Double Standards, Delegitimization. Jewish Political Studies Review, 16: 3-4.

Shroufi, O., 2015. The Gates of Jerusalem: European revisionism and the populist radical Right. Race \& Class, 57(2): 24-42.

Silver, C., 2016. How an Israeli group plans to infiltrate human rights monitors. Electronic Intifada. Available at https://electronicintifada.net/blogs/charlotte-silver/how-israeli-groupplans-infiltrate-human-rights-monitors

Simpson, W., 2016. Easton Cowboys and Cowgirls: anatomy of an alternative sports club, Soccer \& Society, 17 (5): 721-731.

Sorek, T., 2007. Arab Soccer in a Jewish state. The integrative enclave. Cambridge, Cambridge University Press. 
Srikanth, R., 2015. South African Solidarity with Palestinians: Motivations, Strategies, and Impact, New England Journal of Public Policy: 27(1): 3. Available at:

http://scholarworks.umb.edu/nejpp/vol27/iss 1/3

Stanislawski, M., 2016. Zionism: A Very Short Introduction. Oxford, OU Press.

Sugden, J., 2010. Critical left-realism and sport interventions in divided societies. International Review for the Sociology of Sport, 45(3): 258-272.

Tait, R., 2013. British guile of disguised anti-Semitism, says Israeli minister. Telegraph. Available at http://www.telegraph.co.uk/news/worldnews/middleeast/israel/10074775/British-guilty-ofdisguised-anti-Semitism-says-Israeli-minister.html

Tawil-Souri, H. (2011) Colored Identity. The Politics and Materiality of ID Cards in Palestine/Israel. Social Text. 29(2): 107: 67-97

Turner, M., 2015. Creating a counterhegemonic praxis: Jewish-Israeli activists and the challenge to Zionism. Conflict, Security \& Development, 15:5, 549-574.

Warschawski, M., 2016. Habima Theater and the need for a cultural boycott of Israel. Available at http://alternativenews.org/index.php/comment/237-habima-theater-and-the-needfor-a-cultural-boycott-of-israel

Weinthal, B., 2014. Why Europe blames Israel for the Holocaust: Post-1945 anti-Semitism. The Jerusalem Post. Available at http://www.jpost.com/Jewish-World/Jewish-Features/WhyEurope-blames-Israel-for-the-Holocaust-Post-1945-anti-Semitism-339571

White, B., 2011. Palestinians in Israel: Segregation, Discrimination and Democracy. London, Pluto Press.

Zertal, I. and Eldar, A., 2007. Lords of the Land. The War over Israel's Settlements in the Occupied Territories, 1967-2007. New York: Nation Books.

Zirin, D., 2014. Are Gaza Protests Coming to the NBA Preseason? The Nation. Available at https://www.thenation.com/article/are-gaza-protests-coming-nba-preseason/

\footnotetext{
1 After the defeat of Turkey and the end of the Ottoman Empire in the first part of the 20th century (Rogan 2016), Britain and France took control over much of the Middle East (Barr 2012). Britain assumed control over Palestine and governed under a mandate until 1948 when it relinquished control to the United Nations. During this period the British tried, unsuccessfully, to appease both the Arab and Jewish populations (Schneer 2011; Segev 2001).
} 
2 The 'US-Israel Trade and Commercial Enhancement Act' (June 2015) increased risks for those participating in restrictions against Israel (see Turner 2015). However, in the UK, the government failed in its attempt to prevent local authorities from adopting ethical procurement and investment policies in support of the Palestinian-led BDS movement (IMEMC 2016).

3 Although all citizens of Israel hold Israeli citizenship, there is no Israeli 'nationality' so ID cards, for instance, note whether the holder is Jewish, Arab or 'other' (Tawil-Souri 2011).

4 In the same way that the BDS movement gives voice to the Palestinians, it is important not to ignore the Jewish voice. There is increased awareness of not speaking on behalf of a group ('mansplain/whitesplain'), and so the presence of Jews within Pro-Palestinian groups is seen as essential, as is the need to respect all people's right to self-define and avoid non-Jews speaking on behalf of the Jews and commenting on what is, and what is not, antisemitism (Burston 2016).

5 Insufficient space here prevents a full discussion of this issue, but see Greenstein (2011) and Jacobs and Soske (2015).

6 Through the Balfour Declaration, Sykes/Picot agreement, and Mandate (1920-1948).

7 The Palestinian population is primarily, but not exclusively, Sunni Muslim, with a small Christian community and even smaller Druze and Samaritan communities. 